\title{
Assessment of the physiological potential of super sweet corn seeds ${ }^{1}$
}

\author{
Renata Oliveira Alvarenga ${ }^{2 *}$, Julio Marcos-Filho $^{2}$, Tathiana Silva Timóteo
}

\begin{abstract}
The assessment of physiological potential is essential in seed quality control programs. This study compared the sensitivity of different procedures for evaluating super sweet corn seed vigor, focusing on the primary root protrusion test. Six seed lots, each of the SWB 551 and SWB 585 hybrids, were used. Seed physiological potential was evaluated by germination and vigor tests (speed of germination, traditional and saturated salt accelerated aging, cold test, seedling length, seedling emergence and primary root protrusion). Primary root protrusion was evaluated every 12 hours at $15{ }^{\circ} \mathrm{C}, 20^{\circ} \mathrm{C}$ and $25^{\circ} \mathrm{C}$ using two criteria (primary root protrusion and seedlings at the $2 \mathrm{~mm}$ root stage). It was concluded that the primary root protrusion test at $15^{\circ} \mathrm{C}$ can evaluate super sweet corn seed vigor by counting the number of seedlings at the $2 \mathrm{~mm}$ root stage.
\end{abstract}

Index terms: Zea mays L., seed testing, germination, vigor, primary root.

\section{Testes para avaliação do potencial fisiológico de sementes de milho superdoce}

\begin{abstract}
RESUMO - A avaliação eficiente do potencial fisiológico é fundamental para a composição de programas de controle de qualidade de sementes. O objetivo do presente trabalho foi verificar a eficiência de diferentes procedimentos para diferenciar o vigor de lotes de sementes de milho superdoce, com ênfase ao teste de emissão da raiz primária. Utilizaram-se sementes dos híbridos SWB 551 e SWB 585, cada um representado por seis lotes. A avaliação do potencial fisiológico foi efetuada mediante a condução de testes de germinação e de vigor (velocidade de germinação, envelhecimento acelerado tradicional e com solução saturada de $\mathrm{NaCl}$, teste de frio, comprimento e emergência de plântulas e emissão da raiz primária). No teste de emissão da raiz primária, foram avaliados, a cada 12 horas, os efeitos de três temperaturas $\left(15^{\circ} \mathrm{C}, 20^{\circ} \mathrm{C}\right.$ e $25^{\circ} \mathrm{C}$ ), utilizando-se dois critérios (protrusão da raiz primária e registro de plântulas com raiz primária de, pelo menos, $2 \mathrm{~mm}$ de comprimento). Concluiu-se que o teste de emissão da raiz primária a $15^{\circ} \mathrm{C}$, quando são computadas plântulas com raiz primária de, no mínimo, $2 \mathrm{~mm}$ de comprimento, é sensível para a avaliação do potencial fisiológico de sementes de milho superdoce.
\end{abstract}

Termos para indexação: Zea mays L., análise de sementes, germinação, vigor, raiz primária.

\section{Introduction}

Sweet corn is classified as a special corn and is exclusively for human consumption. Its seeds generally have a low physiological potential due to various factors, including high sensitivity to damage by imbibition, a fragile membrane system after drying, low amide content and a high quantity of sugars in the endosperm. This consequently results in susceptibility to microorganisms since sugars become a substrate for pathogen growth on the seed surface (Styer and Cantliffe, 1983; Douglas et al., 1993).

Seed physiological potential is routinely evaluated by the germination test conducted under theoretically ideal conditions. However, seed lots with similar germination may show distinct performances in the field when conditions are not ideal. Therefore, vigor tests were developed to complement the information obtained from the germination test with the aim of estimating seed potential under a wide variety of environmental conditions (AOSA, 1983).

Among the most common vigor tests are those based on seedling behavior. These are classified as physiological tests (McDonald, 1975), since they try to determine specific physiological activity, which depends on vigor. They include germination speed, seedling emergence speed and seedling length tests, which have desirable characteristics for a vigor test because they are simple to do, fast and cheap.

Despite the advantages of these seedling development tests, they have generally been considered less sensitive for detecting small vigor differences compared to those which evaluate stress tolerance (Marcos-Filho, 2005), such as, for

${ }^{1}$ Submitted on 11/30/2012. Accepted for publication on 04/04/2013.

${ }^{2}$ Departamento de Produção Vegetal, USP/ESALQ, Caixa Postal 9, 13418-900 - Piracicaba, SP, Brasil.

*Corresponding author <realvarenga7@gmail.com> 
example, accelerated aging and cold tests. After Torres (1998) evaluated the efficiency of different tests to determine the physiological potential of corn seeds, he concluded that the cold and accelerated aging tests should be recommended to differentiate different vigor levels in corn seed.

Beside these tests, the primary root protrusion test, although little studied, is easy to do and promising for determining corn seed vigor (Toledo et al., 1999; Matthews and Khajeh-Hosseini, 2006, 2007; Khajeh-Hosseini et al., 2009). The Executive Committee of ISTA (International Seed Testing Association) recently approved the inclusion of the primary root protrusion test, as an additional method for evaluating corn seed vigor, in the International Rules for Seed Analysis, (ISTA, 2011).

Although seedlings cannot be evaluated from the early protrusion of the primary root based on the rules established by the Seed Analysis Rules (Brasil, 2009), this test can estimate corn seed vigor since it associates the number of seeds which emit the primary root with the germination speed (Toledo et al., 1999).

There is research with other species, such as tomatoes (Martinelli-Seneme et al., 2004), cabbage-broccoli (Martins et al., 2002) and pepper (Demir et al., 2008), which describe the possible use of the primary root protrusion test to evaluate vigor.

Since information about the efficiency of vigor tests to evaluate the physiological potential of super sweet corn seeds is relatively scarce, studies should continue. The objective of the current study is to evaluate the efficiency of different tests, especially of primary root protrusion, to obtain data, which can offer alternative tests to use in quality control programs.

\section{Material and Methods}

The research was done at the Seed Analysis Laboratory of the Plant Production Department of ESALQ (Escola Superior de Agricultura "Luiz de Queiroz"), São Paulo University (USP), in Piracicaba, São Paulo state. The experiment included evaluations of the performance of super sweet corn seeds in two time periods, three months apart.

Two super sweet corn hybrids (sh2) were used, SWB 551 and SWB 585, supplied by Dow AgroSciences, each represented by six seed lots, treated with a fungicide and an insecticide. Lots with different physiological potentials were obtained by submitting part of the seed samples of each hybrid to artificial aging.

Two seed lots of the SWB 551 hybrid were received, weighing $1.3 \mathrm{~kg}$ (lot 1) and $8.7 \mathrm{~kg}$ (lot 2), respectively. Lot 1 was kept unchanged, whereas lot 2 was divided into four portions: three were artificially aged at $41^{\circ} \mathrm{C}$ for 24,48 and
72 hours, constituting lots 3,4 and 5, respectively. Lot 6 was obtained by mixing $250 \mathrm{~g}$ of lot 2 with $170 \mathrm{~g}$ of lot 3 , based on the results of preliminary physiological potential tests.

A similar procedure was used to obtain seed lots for the SWB 585 hybrid, with lot 7 corresponding to seeds not aged artificially and lots 8,9 and 10 to seeds aged at $41{ }^{\circ} \mathrm{C}$, for 12, 24 and 48 hours respectively. Lot 11 was obtained by mixing $290 \mathrm{~g}$ of lot 7 with $292 \mathrm{~g}$ of lot 8 , and lot 12 by mixing $408 \mathrm{~g}$ of lot 7 with $175 \mathrm{~g}$ of lot 9 , also based on preliminary test results.

After aging and careful homogenization of each seed lot, the seeds were dried at room temperature (around $25{ }^{\circ} \mathrm{C}$ ), until water content was close to initial levels ( $8.3 \%$ to $9.9 \%$ ). Later, the seeds of each lot were placed in Kraft paper bags and stored in a dry chamber $\left(20{ }^{\circ} \mathrm{C}\right.$ and $50 \%$ air humidity) during the experiment. The following evaluations were made: seed moisture content - measured before the germination and vigor tests using the oven method at $105^{\circ} \mathrm{C}\left( \pm 3{ }^{\circ} \mathrm{C}\right)$, for 24 hours (Brasil, 2009), with two replications for each lot. The results were expressed in mean percentage (wet basis) per lot; germination - with four replications of 50 seeds per lot, in paper towel rolls, moistened with an amount of water equivalent to 2.5 times the weight of dry paper at $25{ }^{\circ} \mathrm{C}$, for seven days. Evaluations were made according to criteria established by the Seed Analysis Rules (Brasil, 2009) and the results expressed as the mean percentage of normal seedlings per lot; germination speed - determined during the germination test from daily counts of normal seedlings until the data stabilized. The germination speed index was calculated according to Maguire (1962), and the results expressed in mean indices for each lot; accelerated aging (traditional and with a saturated solution of $\mathrm{NaCl}$ ) - using plastic boxes $(11.0 \times 11.0 \times 3.0 \mathrm{~cm})$ with internal metal mesh supports on which seeds were distributed in a single layer. Inside each box were added $40 \mathrm{~mL}$ of water or saturated $\mathrm{NaCl}$ solution. The boxes were kept sealed and in B.O.D. chambers at $41{ }^{\circ} \mathrm{C}$ for 72 hours (Hampton and TeKrony, 1995). After this, the germination test was done and evaluated four days after sowing. The seed moisture content was also determined after aging to observe if test conditions were uniform; cold test - plastic trays $(34 \times 23 \times 7 \mathrm{~cm})$ were used with $1 \mathrm{~kg}$ of substrate (soil/sand mixture). Two replications of 50 seeds were distributed on each tray and covered with $1 \mathrm{~kg}$ of substrate. Water availability in the substrate was adjusted to $70 \%$ of the retention capacity. The water used was previously cooled to $10{ }^{\circ} \mathrm{C}$. Evaporation was reduced by protecting the trays with a plastic bag and transferring them to a cold chamber at $10{ }^{\circ} \mathrm{C}$, for seven days. The trays were then kept in a germinator at $25^{\circ} \mathrm{C}$ and the number of normal seedlings 
counted five days later (Caseiro and Marcos-Filho, 2000); seedling length - the substrate was prepared as described for the germination test, with four replications of 20 seeds per lot. The seeds were distributed on the upper third of a paper towel with the radicle tip pointing towards the lower part of the towel. The rolls were kept in a germinator at $25{ }^{\circ} \mathrm{C}$ for four days, after which the length of the normal seedlings was measured. Results were expressed in mm.seedling ${ }^{-1}$, to one decimal place (Nakagawa, 1999); primary root protrusion (protrusion) - with four replications of 50 seeds from each lot, distributed on moist paper towel sheets, with an amount of water equivalent to 2.5 times the weight of dry paper, and kept in a germinator at $15^{\circ} \mathrm{C}, 20^{\circ} \mathrm{C}$ and $25^{\circ} \mathrm{C}$. The number of seeds which emitted a primary root (protrusion) was counted every 12 hours and classified as criterion 1 . Later, the primary root protrusion precocity index was calculated according to Maguire's (1962) formula for calculating the germination speed index; primary root protrusion (root length $\geq 2 \mathrm{~mm}$ ) done according to procedure already described for primary root protrusion (protrusion); the number of seeds, which emitted a primary root at least $2 \mathrm{~mm}$ long was counted every 12 hours (criterion 2). The primary root protrusion precocity index was calculated in a similar manner; field seedling emergence with four replications of 50 seeds, each one represented by a $4 \mathrm{~m}$ long row, $40 \mathrm{~cm}$ apart, where the seeds were distributed equidistantly in furrows $7 \mathrm{~cm}$ deep and covered with about 3 $\mathrm{cm}$ of earth. Seedling emergence was evaluated 14 days after sowing, registering the mean percentage of emerged normal seedlings for each lot. The emergence speed index was also calculated according to Maguire's (1962) formula. Statistical procedure: the experimental design was completely random (laboratory tests) and with random blocks (field tests) and the data were submitted to an analysis of variance. Means were compared using Duncan's test $(\mathrm{p} \leq 0.05)$.

\section{Results and Discussion}

Both hybrids had seeds with an initial moisture content between $8.3 \%$ and $9.9 \%$ for the two experimental periods. After traditional accelerated aging (TAA), these values varied from $29.7 \%$ to $31.8 \%$ and from $29.7 \%$ to $32.7 \%$ for the seeds of the SWB 551 and SWB 585 hybrids respectively; after saturated salt accelerated aging (SSAA), water content varied between $11.6 \%$ and $12.7 \%$. This factor, therefore, did not affect seed behavior during the tests since variations occurred within acceptable limits (Marcos-Filho, 1999b). The lower variation between the samples submitted to SSAA was foreseen because this happens in an environment with a lower humidity (approximately 75\%), favoring a slower, more uniform and less intense absorption of water compared to TAA.

During the experimental period, the lots of both hybrids showed more than $60 \%$ germination (Tables 1 and 2), the minimum value established for super sweet corn seed sales in Brazil (Brasil, 2005). This is important since vigor tests should compare the performance of lots which follow the requirements established for commercialization and should have similar germination values (Powell, 1986).

The analyses of variance of the SWB 551 hybrid data for the two experimental periods showed significant effects between the lots for all the parameters evaluated. Lot 1 showed the worst performance for all the tests but there were variations for the identification of the most vigorous lot (Tables 1 and 3). The superiority of any lot for percentage and speed of germination and percentage seedling field emergence was not evident from the results for the first experimental period (Table 1); however, in the second period, these tests indicated that lot 6 tended to be superior. Lot 2 was the most vigorous for seedling emergence speed for both periods but lot 6 also gave a similar result for the second period.

For the SWB 585 hybrid lots, the percentage germination and the percentage seedling field emergence were the same for both experimental periods (Table 2). In the second period, there was no significant variation between lots for germination speed and seedling field emergence speed. The physiological potential of the lots for this hybrid was closer, making it difficult to identify different vigor levels. However, for the first period the germination speed and seedling emergence speed showed a worse result for lots 10 and 9, respectively and identified superior vigor in lot 12 . MarcosFilho (1999a) has observed that the manifestation of vigor is directly influenced by the environment and, therefore, tests based on seedling development, such as germination speed and seedling emergence speed may not be sensitive enough to detect small differences in physiological potential if environmental conditions are very favorable for germination.

The importance of temperature in the manifestation of seed physiological processes may be seen from the cold and accelerated aging tests. The numerical values obtained in the cold test were very low for both hybrids, demonstrating the sensitivity of these hybrids to low temperatures and making the separation of lots for vigor more difficult. For this reason, the data from the cold tests have not been included.

On the other hand, the lots of both hybrids could be separated for vigor by using high temperatures and humidities in the accelerated aging tests, without provoking drastic effects (Tables 1 and 2). This may indicate that the genotypes used are less sensitive to high temperatures than to a low temperature. 
Table 1. Mean values of germination (G), germination speed index (GSI), percentage (P) and emergence speed index (SI) of field seedlings, traditional accelerated aging (TAA) and with a saturated salt solution (SSAA) and seedling length (SL) for six lots of super sweet corn seed SWB 551, in two different experimental periods.

\begin{tabular}{|c|c|c|c|c|c|c|c|c|}
\hline \multirow{2}{*}{ Period } & \multirow{2}{*}{ Lots } & $\mathrm{G}$ & GSI & $\mathrm{P}$ & SI & TAA & SSAA & $\mathrm{SL}$ \\
\hline & & $(\%)$ & (index) & $(\%)$ & (index) & $(\%)$ & $(\%)$ & $\left(\mathrm{mm}\right.$. seedling $\left.^{-1}\right)$ \\
\hline \multirow{7}{*}{ First } & 1 & $72 \mathrm{~B}(*)$ & $7.8 \mathrm{~B}$ & $60 \mathrm{~B}$ & $4.8 \mathrm{C}$ & $44 \mathrm{D}$ & $22 \mathrm{C}$ & $44.6 \mathrm{C}$ \\
\hline & 2 & $91 \mathrm{~A}$ & $11.7 \mathrm{~A}$ & $84 \mathrm{~A}$ & $7.2 \mathrm{~A}$ & $79 \mathrm{AB}$ & $82 \mathrm{~A}$ & $106.7 \mathrm{AB}$ \\
\hline & 3 & $91 \mathrm{~A}$ & $12.0 \mathrm{~A}$ & $82 \mathrm{~A}$ & $6.7 \mathrm{AB}$ & $75 \mathrm{ABC}$ & $73 \mathrm{~B}$ & $116.9 \mathrm{AB}$ \\
\hline & 4 & $86 \mathrm{~A}$ & $11.4 \mathrm{~A}$ & $77 \mathrm{~A}$ & $6.1 \mathrm{~B}$ & $67 \mathrm{C}$ & $76 \mathrm{AB}$ & $103.8 \mathrm{~B}$ \\
\hline & 5 & $86 \mathrm{~A}$ & $11.4 \mathrm{~A}$ & $81 \mathrm{~A}$ & $6.7 \mathrm{AB}$ & $70 \mathrm{BC}$ & $81 \mathrm{~A}$ & $114.9 \mathrm{AB}$ \\
\hline & 6 & $93 \mathrm{~A}$ & $11.9 \mathrm{~A}$ & $78 \mathrm{~A}$ & $6.5 \mathrm{AB}$ & $80 \mathrm{~A}$ & $78 \mathrm{AB}$ & $132.0 \mathrm{~A}$ \\
\hline & CV (\%) & 6.7 & 5.3 & 7.3 & 7.3 & 8.2 & 6.8 & 16.1 \\
\hline \multirow{7}{*}{ Second } & 1 & $68 \mathrm{C}$ & $9.2 \mathrm{C}$ & $56 \mathrm{C}$ & $5.0 \mathrm{C}$ & $43 \mathrm{C}$ & $27 \mathrm{~B}$ & $117.8 \mathrm{D}$ \\
\hline & 2 & $91 \mathrm{AB}$ & $13.5 \mathrm{AB}$ & $88 \mathrm{AB}$ & $8.7 \mathrm{~A}$ & $82 \mathrm{~A}$ & $80 \mathrm{~A}$ & $177.9 \mathrm{~A}$ \\
\hline & 3 & $90 \mathrm{AB}$ & $13.1 \mathrm{AB}$ & $81 \mathrm{~B}$ & $7.4 \mathrm{~B}$ & $75 \mathrm{AB}$ & $79 \mathrm{~A}$ & $140.5 \mathrm{CD}$ \\
\hline & 4 & $88 \mathrm{~B}$ & $12.6 \mathrm{~B}$ & $83 \mathrm{AB}$ & $7.7 \mathrm{~B}$ & $71 \mathrm{~B}$ & $75 \mathrm{~A}$ & $147.5 \mathrm{BC}$ \\
\hline & 5 & $89 \mathrm{~B}$ & $13.0 \mathrm{AB}$ & $82 \mathrm{AB}$ & $7.8 \mathrm{~B}$ & $70 \mathrm{~B}$ & $73 \mathrm{~A}$ & $153.1 \mathrm{BC}$ \\
\hline & 6 & $97 \mathrm{~A}$ & $14.1 \mathrm{~A}$ & $89 \mathrm{~A}$ & $8.6 \mathrm{~A}$ & $80 \mathrm{~A}$ & $75 \mathrm{~A}$ & $167.5 \mathrm{AB}$ \\
\hline & CV (\%) & 5.1 & 6.4 & 6.0 & 6.1 & 7.7 & 11.2 & 10.3 \\
\hline
\end{tabular}

(*) Means followed by the same letter (within each column) do not differ among themselves according to Duncan's test, $\mathrm{p} \leq 0.05$.

Table 2. Mean values of germination (G), germination speed index (GSI), percentage (P) and emergence speed index (SI) of field seedlings, traditional accelerated aging (TAA) and with a saturated salt solution (SSAA) and seedling length (SL) for six lots of super sweet corn seed SWB 585, in two different experimental periods.

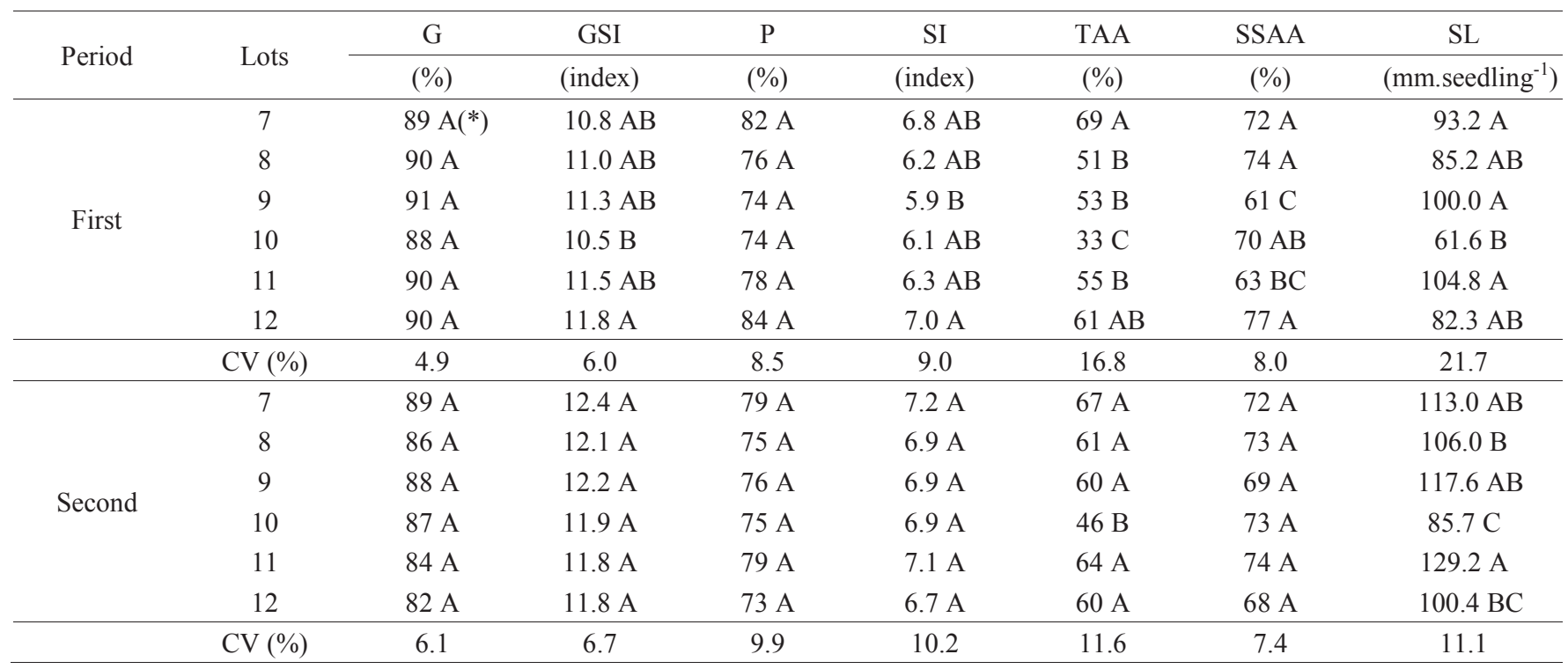

(*) Means followed by the same letter (within each column) do not differ among themselves according to Duncan's test, $\mathrm{p} \leq 0.05$.

The results of the traditional accelerated aging test (TAA) for the SWB 551 hybrid in both experimental periods showed that the better performance of lot 6 was accompanied by lot 2 in the second period (Table 1). This was also seen for seedling emergence speed for lot 2. The efficiency of the traditional accelerated aging test has been confirmed by Santos et al. (2002), using temperatures of $45{ }^{\circ} \mathrm{C}$ and $42{ }^{\circ} \mathrm{C}$ for 24 and 72 hours, respectively, to differentiate super sweet corn seed lots into different vigor levels. However, for the saturated salt accelerated aging test (SSAA), the more vigorous lots were only identified for the first period (lots 2 and 5). For the SWB 585 hybrid, results from the traditional test showed that lot 10 gave the worst 
performance for both periods and that lot 7 was identified as the most vigorous in the first period and with a tendency to be superior in the second period (Table 2). However, the test with the saturated solution of $\mathrm{NaCl}$ separated the lots for vigor only for the first period, indicating lot 9 to have the least vigor. It can be seen for this test (SSAA) that lot 10 did not differ from the best lots. This probably occurred because the seeds absorbed less water, more slowly, resulting in a lower deterioration rate, and consequently, less variable results.

Thus the results showed that for the SWB 551 hybrid, the traditional accelerated aging and seedling emergence speed tests were similar for both time periods; for the SWB 585 hybrid, only the traditional accelerated aging test was sensitive enough to differentiate lot vigor in both experimental periods.

The seedling length test was also efficient for separating the lots of both hybrids for vigor (Tables 1 and 2). The results for the SWB 551 hybrid showed that lot 6 gave the best performance in the first period and lot 2 in the second period. These results were similar for both periods with those obtained for the traditional accelerated aging test. Teixeira et al. (2006) also observed similar results for corn lot vigor between seedling length and traditional accelerated aging tests. For the SWB 585 hybrid in both periods, the results of the seedling length test showed lot 10 as having the worst performance and lot 11 the best performance in the second period (Table 2). There was also coherence in this hybrid between the results obtained in the seedling length and traditional accelerated aging tests, regarding the least vigorous lot in both periods.

Table 3 shows the results of the primary root protrusion test for the SWB 551 hybrid. In the first period, for the primary root protrusion test done at $25{ }^{\circ} \mathrm{C}$ (criterion 2), lots 2 and 6 were identified as the most vigorous; for the tests done at $15{ }^{\circ} \mathrm{C}$ and $20{ }^{\circ} \mathrm{C}$, lot 2 showed the best performance considering both criteria. In general, the results of the primary root protrusion test for the second period were similar to those obtained in the first period, showing the superiority of lot 2, accompanied or not by other lots (4 or 6). These results agreed with those obtained for seedling emergence speed, traditional accelerated aging and seedling length (Table 1). Similarly, Matthews and Khajeh-Hosseini (2006) observed a close relationship between primary root protrusion (primary root protrusion or when seedlings have a primary root at least $2 \mathrm{~mm}$ long) at $13{ }^{\circ} \mathrm{C}$, and the mean time for seedling field emergence; the corn seed lots which emitted the primary root more quickly also had faster seedling emergence.

Table 3. Mean indices of precocity of primary root protrusion at $15{ }^{\circ} \mathrm{C}\left(\mathrm{PRP} 15^{\circ} \mathrm{C}\right), 20^{\circ} \mathrm{C}\left(\mathrm{PRP} 20^{\circ} \mathrm{C}\right)$ and $25{ }^{\circ} \mathrm{C}\left(\mathrm{PRP} 25^{\circ} \mathrm{C}\right)$, considering primary root protrusion (Criterion 1 ) and seedlings with a primary root at least $2 \mathrm{~mm}$ long (Criterion 2), for six lots of super sweet corn seed SWB 551, in two experimental periods.

\begin{tabular}{|c|c|c|c|c|c|c|c|}
\hline \multirow{2}{*}{ Period } & \multirow{2}{*}{ Lots } & \multicolumn{2}{|c|}{ PRP $15^{\circ} \mathrm{C}$} & \multicolumn{2}{|c|}{ PRP $20^{\circ} \mathrm{C}$} & \multicolumn{2}{|c|}{ PRP $25^{\circ} \mathrm{C}$} \\
\hline & & Criterion 1 & Criterion 2 & Criterion 1 & Criterion 2 & Criterion 1 & Criterion 2 \\
\hline \multirow{6}{*}{ First } & 1 & $2.7 \mathrm{C}(*)$ & $2.5 \mathrm{D}$ & $6.8 \mathrm{C}$ & $6.3 \mathrm{C}$ & $12.0 \mathrm{~B}$ & $10.3 \mathrm{C}$ \\
\hline & 2 & $6.3 \mathrm{~A}$ & $5.0 \mathrm{~A}$ & $12.0 \mathrm{~A}$ & $10.1 \mathrm{~A}$ & $16.5 \mathrm{~A}$ & $14.6 \mathrm{~A}$ \\
\hline & 3 & $4.8 \mathrm{~B}$ & $4.4 \mathrm{~B}$ & $11.4 \mathrm{AB}$ & $9.2 \mathrm{~B}$ & $16.1 \mathrm{~A}$ & $13.6 \mathrm{~B}$ \\
\hline & 4 & $4.6 \mathrm{~B}$ & 4.6 AB & $10.7 \mathrm{~B}$ & $8.8 \mathrm{~B}$ & $15.9 \mathrm{~A}$ & $13.8 \mathrm{AB}$ \\
\hline & 5 & $5.0 \mathrm{~B}$ & $3.8 \mathrm{C}$ & $10.8 \mathrm{~B}$ & $9.3 \mathrm{~B}$ & $16.4 \mathrm{~A}$ & $13.5 \mathrm{~B}$ \\
\hline & 6 & $5.1 \mathrm{~B}$ & $3.8 \mathrm{C}$ & $11.2 \mathrm{~B}$ & $9.2 \mathrm{~B}$ & $16.9 \mathrm{~A}$ & $14.5 \mathrm{~A}$ \\
\hline & CV (\%) & 9.7 & 7.9 & 4.3 & 5.9 & 5.0 & 4.3 \\
\hline \multirow{7}{*}{ Second } & 1 & $1.8 \mathrm{C}$ & $1.8 \mathrm{C}$ & $4.7 \mathrm{C}$ & $4.8 \mathrm{C}$ & $10.2 \mathrm{C}$ & $7.6 \mathrm{C}$ \\
\hline & 2 & $4.9 \mathrm{~A}$ & $3.7 \mathrm{~A}$ & $8.9 \mathrm{~A}$ & $8.1 \mathrm{~A}$ & $16.1 \mathrm{~A}$ & $13.6 \mathrm{~A}$ \\
\hline & 3 & $3.9 \mathrm{~B}$ & $3.0 \mathrm{~B}$ & $7.9 \mathrm{AB}$ & $7.0 \mathrm{~B}$ & $14.8 \mathrm{AB}$ & $12.4 \mathrm{AB}$ \\
\hline & 4 & $5.0 \mathrm{~A}$ & $3.7 \mathrm{~A}$ & $8.3 \mathrm{AB}$ & $8.1 \mathrm{~A}$ & $14.8 \mathrm{AB}$ & $12.1 \mathrm{~B}$ \\
\hline & 5 & $4.3 \mathrm{AB}$ & $3.0 \mathrm{~B}$ & $7.4 \mathrm{~B}$ & $6.6 \mathrm{~B}$ & $14.2 \mathrm{~B}$ & $12.1 \mathrm{~B}$ \\
\hline & 6 & $4.2 \mathrm{~B}$ & $3.2 \mathrm{AB}$ & $8.8 \mathrm{~A}$ & $6.9 \mathrm{~B}$ & $16.0 \mathrm{~A}$ & $12.7 \mathrm{AB}$ \\
\hline & CV (\%) & 11.6 & 14.0 & 10.2 & 7.7 & 6.3 & 6.8 \\
\hline
\end{tabular}

(*) Means followed by the same letter (within each column) do not differ among themselves according to Duncan's test, $\mathrm{p} \leq 0.05$.

The primary root protrusion tests could detect differences in vigor between seed lots of the SWB 551 hybrid since the results agreed with those from the germination speed, seedling field emergence (percentage and speed), seedling length and traditional accelerated aging tests (Table 1).

For the SWB 585 hybrid in the first period (Table 4), the 
primary root protrusion test at $15{ }^{\circ} \mathrm{C}$ (criterion 1), identified lot 10 as being the least vigorous; however, according to criterion 2, besides showing lot 10 as having the worst performance, lot 12 was shown to be the most vigorous, agreeing with the results of the germination speed test (Table 2). This agreement may be explained by the fact that these tests are based on the first evaluations of seedling development. In general, the poor performance of lot 10 could also be seen in the test done at $20^{\circ} \mathrm{C}$ and at $25^{\circ} \mathrm{C}$; in these tests, lots $11\left(\right.$ at $20^{\circ} \mathrm{C}$ ) and $8\left(\right.$ at $25^{\circ} \mathrm{C}$ ) were shown to be the most vigorous.

Table 4. Mean indices of precocity of primary root protrusion at $15{ }^{\circ} \mathrm{C}\left(\mathrm{PRP} 15^{\circ} \mathrm{C}\right), 20^{\circ} \mathrm{C}\left(\mathrm{PRP} 20^{\circ} \mathrm{C}\right)$ and $25^{\circ} \mathrm{C}\left(\mathrm{PRP} 25^{\circ} \mathrm{C}\right)$, considering primary root protrusion (Criterion 1) and seedlings with a primary root at least $2 \mathrm{~mm}$ long (Criterion 2), for six lots of super sweet corn seed SWB 585, in two experimental periods.

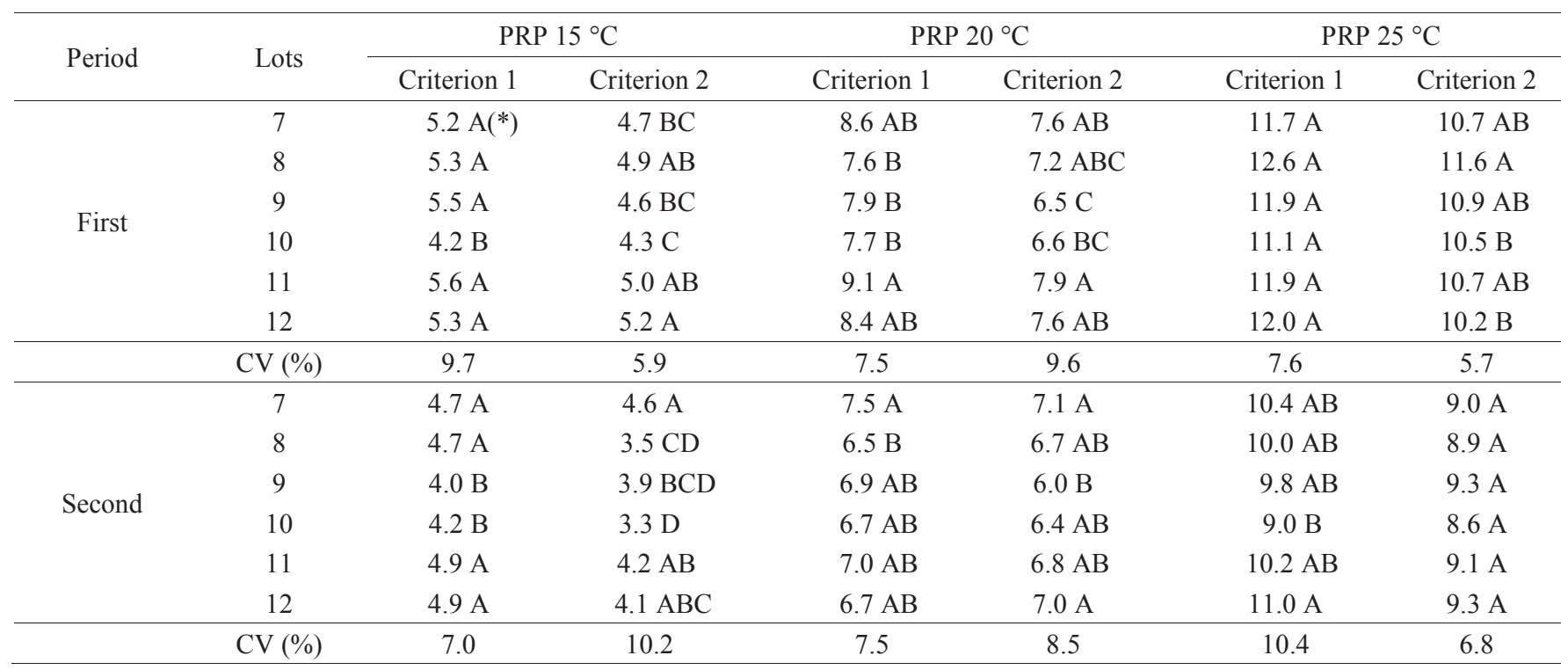

(*) Means followed by the same letter (within each column) do not differ among themselves according to Duncan's test, $\mathrm{p} \leq 0.05$.

In the second evaluation period, the results from the test done at $15^{\circ} \mathrm{C}$ (criteria 1 and 2) confirmed the worst performance for lot 10; this lot was also identified as the least vigorous in the test done at $25{ }^{\circ} \mathrm{C}$ (criterion 1). However, at $20^{\circ} \mathrm{C}$, lots 8 (criterion 1) and 9 (criterion 2) were the least vigorous. There was a variation for the most vigorous lot between the results for the three temperatures, with lots 7 and/or 12 standing out, differing from the results from the first experimental period.

Since the differences between the physiological potential of the SWB 585 hybrid seeds were smaller, it is worth emphasizing that in the second experimental period, the primary root protrusion test was one of the few tests where lot differences for vigor could be differentiated, usually giving similar results to those from the traditional accelerated aging and seedling length tests.

An evaluation of results from both seasons shows that for the SWB 551 hybrid, the traditional accelerated aging, seedling emergence speed and primary root protrusion tests at $15^{\circ} \mathrm{C}$ (criteria 1 and 2), $20^{\circ} \mathrm{C}$ (criteria 1 and 2) and $25^{\circ} \mathrm{C}$ (criterion 2), produced similar results for both periods, with lot 1 being the worst and lots 2 or 6 the best.

The test results for the SWB 585 hybrid in both seasons only identified the worst lot. Thus, the primary root protrusion at 15 ${ }^{\circ} \mathrm{C}$ (criteria 1 and 2), seedling length and traditional accelerated aging tests gave comparable results in both periods, identifying lot 10 as the least vigorous; only the primary root protrusion at 15 ${ }^{\circ} \mathrm{C}$ (criterion 2) among the tests, identified the most vigorous lot in both periods but differently (lot 12 in the first and lot 7 in the second period). This may have been due to the composition of lot 12 , where $70 \%$ of the seeds came from lot 7 .

Therefore, among all the tests done on the two hybrids, the most sensitive one to evaluate super sweet corn seed vigor was the primary root protrusion test at $15{ }^{\circ} \mathrm{C}$ (criterion 2). According to ISTA (2011), the primary root protrusion test can be done at $13{ }^{\circ} \mathrm{C}$ or at $20{ }^{\circ} \mathrm{C}$; these temperatures were successfully used to evaluate corn seed vigor (Matthews and Khajeh-Hosseini, 2006, 2007; Khajeh-Hosseini et al., 2009). Therefore, the primary root protrusion test is a promising alternative for inclusion in quality control programs since it has desirable characteristics for a vigor test, namely: objectivity, repeatability, simplicity and low cost, thus contributing to the efficient evaluation of seed physiological potential. However, this research should continue in order to 
improve the methodology so that it can be standardized.

\section{Conclusions}

The primary root protrusion test at $15{ }^{\circ} \mathrm{C}$ with primary roots at least $2 \mathrm{~mm}$ long, allows super sweet corn seeds to be differentiated for vigor and results are comparable to the traditional tests used for this specie.

\section{Acknowledgements}

To FAPESP and CNPq for granting study scholarships and financing this research and to Dow AgroSciences for supplying the seeds.

\section{References}

AOSA - ASSOCIATION OF OFFICIAL SEED ANALYSTS. Seed vigor testing handbook. East Lansing: AOSA, 1983. 88p. (Contribution, 32).

BRASIL. Ministério da Agricultura, Pecuária e Abastecimento. Padrões para produção e comercialização de sementes de milho - cultivares híbridas. Instrução normativa $\mathrm{n}^{\circ} 25$, de 16 de dezembro de 2005. Diário Oficial, Brasília, sec.1, n.243, p.18 de 20/12/2005, 2005.

BRASIL. Ministério da Agricultura, Pecuária e Abastecimento. Regras para análises de sementes. Ministério da Agricultura, Pecuária e Abastecimento. Secretaria de Defesa Agropecuária. Brasília, DF: MAPA/ACS, 2009. 395p. http://www.bs.cca.ufsc.br/publicacoes/regras\%20analise\%20sementes.pdf

CASEIRO, R.F.; MARCOS-FILHO, J. Métodos alternativos do teste de frio para avaliação do vigor de sementes de milho. Scientia Agricola, v.57, n.3, p.459-466, 2000. http://www.scielo.br/scielo.php?script=sci pdf\&pid=s0103-90162000000300014\&lng $=$ pt\&nrm=iso\&tlng $=$ pt

DEMIR, I.; ERMIS, S.; MAVI, K.; MATTHEWS, S. Mean germination time of pepper seed lots (Capsicum annuиm L.) predicts size and uniformity of seedlings in germination tests and transplant modules. Seed Science and Technology, v.36, n.1, p.21-30, 2008. http://www.ingentaconnect.com/ content/ista/sst/2008/00000036/00000001/art00002

DOUGLAS, S.K.; JUVIK, J.A.; SPLITTSTOESSER, W.E. Sweet corn seedling emergence and variation in kernel carbohydrate reserves. Seed Science and Technology, v.21, n.3, p.433-445, 1993.

HAMPTON, J.G.; TEKRONY, D.M. Handbook of vigour test methods. 3.ed. Zurich: ISTA, 1995. 117p.

ISTA - INTERNATIONAL SEED TESTING ASSOCIATION. Addition of a new vigour method approved by ECOM decision n. 648. Minutes of the Ordinary Meeting 2011. p.81-84, 2011. https://www.seedtest.org/upload/ cms/user/om12-02minutesoftheordinarymeeting20111.pdf

KHAJEH-HOSSEINI, M.; LOMHOLT, A.; MATTHEWS, S. Mean germination time in the laboratory estimates the relative vigour and field performance of commercial seed lots of maize (Zea mays L.). Seed Science and Technology, v.37, n.2, p.446-456, 2009. http://www.ingentaconnect.com/ content/ista/sst/2009/00000037/00000002/art00017

MAGUIRE, J.D. Speed of germination-aid in relation evaluation for seedling emergence vigor. Crop Science, v.2, n.2, p.176-177, 1962.
MARCOS-FILHO, J. Testes de envelhecimento acelerado. In: KRZYZANOWSKI, F.C.; VIEIRA, R.D.; FRANÇA-NETO, J.B. Vigor de sementes: conceitos e testes. Londrina: ABRATES, cap.3, p.1-24, 1999 b.

MARCOS-FILHO, J. Testes de vigor: importância e utilização. In: KRZYZANOWSKI, F.C.; VIEIRA, R.D.; FRANÇA-NETO, J.B. (Ed.). Vigor de sementes: conceitos e testes. Londrina: ABRATES, cap.1, p.1-21, 1999a.

MARCOS-FILHO, J. Fisiologia de sementes de plantas cultivadas. Piracicaba: FEALQ, 2005. 495p.

MARTINELLI-SENEME, A.; MARTINS, C.C.; CASTRO, M.M.; NAKAGAWA, J.; CAVARIANI, J. Avaliação do vigor de sementes peliculizadas de tomate. Revista Brasileira de Sementes, v.26, n.2, p.1-6, 2004. http://www.scielo.br/scielo. php?script=sci_pdf\&pid=S0101-31222004000200001\&lng-pt\&nrm=iso\&tlng-pt

MARTINS, C.C.; MARTINELLI-SENEME, A.; CASTRO, M.M.; NAKAGAWA, J.; CAVARIANI, C. Comparação entre métodos para avaliação do vigor de lotes de sementes de couve-brócolos. Revista Brasileira de Sementes, v.24, n.2, p.96-101, 2002. http://www.scielo.br/scielo.php?script=sci_ pdf\&pid $=$ S0101-31222002000200016\&lng $=$ pt\&nrm=iso \&tlng $=$ pt

MATTHEWS, S.; KHAJEH-HOSSEINI, M. Mean germination time as an indicator of emergence performance in soil of seed lots of maize (Zea mays). Seed Science and Technology, v.34, n.2, p.339-347, 2006. http://www. ingentaconnect.com/content/ista/sst/2006/00000034/00000002/art00009

MATTHEWS, S.; KHAJEH-HOSSEINI, M. Length of the lag period of germination and metabolic repair explain vigour differences in seed lots of maize (Zea mays). Seed Science and Technology, v.35, n.1, p.200-212, 2007. http:// www.ingentaconnect.com/content/ista/sst/2007/00000035/00000001/art00018

McDONALD, M.B. A review and evaluation of seed vigor tests. Proceedings of the Association Official Seed Analysts, v.65, p.109-139, 1975.

NAKAGAWA, J. Testes de vigor baseados no desempenho das plântulas. In: KRZYZANOWSKI, F.C.; VIEIRA, R.D.; FRANÇA-NETO, J.B. (Ed.). Vigor de sementes: conceitos e testes. Londrina: ABRATES, cap.2, p.2.1-2.24, 1999.

POWELL, A.A. Cell membranes and seed leachate conductivity in relation to the quality of seed for sowing. Journal of Seed Technology, v.10, n.2, p.81-100, 1986.

SANTOS, P.M.; GONDIM, T.C.O.; ARAÚJO, E.F.; DIAS, D.C.F.S. Avaliação da qualidade fisiológica de sementes de milho-doce pelo teste de envelhecimento acelerado. Revista Brasileira de Sementes, v.24, n.1, p.91-96, 2002. http://www.scielo.br/scielo.php?script=sci_pdf\&pid=S0101$31222002000100013 \& \operatorname{lng}=\mathrm{pt} \& \mathrm{nrm}=\mathrm{iso} \& \operatorname{tng}=\mathrm{pt}$

STYER, R.C.; CANTLIFFE, D. J. Relationship between environment during seed development and seed vigour of two endosperm mutant of corn. Journal of the American Society for Horticultural Science, v. 108, n.5, p.717-720, 1983.

TEIXEIRA, E.F.; CICERO, S.M.; DOURADO-NETO, D. Análise de imagens digitais de plântulas para avaliação do vigor de sementes de milho. Revista Brasileira de Sementes, v.28, n.2, p.159-167, 2006. http://www.scielo.br/scielo.php?script=sci_ pdf\&pid=S0101-31222006000200022\&lng-pt\&nrm=iso\&tlng-pt

TOLEDO, F.F.; NOVEMBRE, A.D.L.C.; CHAMMA, H.M.C.P.; MACHIETTO, R.W. Vigor de sementes de milho (Zea mays L.) avaliado pela precocidade de emissão da raiz primária. Scientia Agricola, v.56, n.1, p.191196, 1999. http://www.scielo.br/scielo.php?script=sci_arttext\&pid=s010390161999000100026\&lng $=$ pt\&nrm $=$ iso\&tlng $=$ pt

TORRES, S.B. Testes de vigor na avaliação da qualidade fisiológica de sementes de milho. Revista Brasileira de Sementes, v.20, n.1, p.55-59, 1998. http://www.abrates.org.br/revista/artigos/1998/v20n1/artigo10.pdf 